\title{
DE
} DE GRUYTER OPEN

Arch. Min. Sci., Vol. 61 (2016), No 1, p. 83-93

Electronic version (in color) of this paper is available: http://mining.archives.pl

DOI 10.1515/amsc-2016-0007

\author{
PAVEL ZAPLETAL*, PAVEL PROKOP*, MARTIN ŠTEMBERKA*, BEÁTA GIBESOVÁ*, \\ EVA VAVŘÍKOVÁ*, HELENA TRČKOVÁ*
}

THE CALCULATION OF METHANE CONCENTRATION EMITTED FROM THE COAL FACE

\author{
OBLICZANIE STĘŻENIA METANU W REJONIE PRZODKA
}

The Paskov Mine belongs to the company OKD, a.s. with the production of hard coking coal from 1970. The applied mining method is the slabbing method in controlled caving, excavating the coal pillar by means of coal plough equipment loading mine run on rake conveyers and securing the excavation area with individual hydraulic or mechanical supports. The coal face is planned as one of the coal faces in continuous extraction of the seam by a shearer.

Using the shearer at mines in the Paskov Mine is not a novelty. Shearer mining represents some problems. Besides the hazard of methane-air ignition, there is a mixture of coal dust - methane - air, which is more dangerous even in the case of lower concentrations of dust and methane than their individual lower limits of explosiveness. A decision was made then that shearers would gradually be replaced with coal ploughs in all coal faces.

The article contains the calculation of the volume of methane emitted as a result of excavation, determining methane concentration during excavation, lowering the hazard of methane layers being formed, and finally evaluating the suitability of the proposed system of the coal face ventilation.

Keywords: Concentration, methane, ventilation, coal face, shearer loader, hazard

Kopalnia Paskov należy do zakładów OKD, gdzie od lat 70-tych trwa produkcja węgla koksowniczego. Stosowana metoda wydobycia to wybieranie ścianowe grubych pokładów z prowadzeniem stropu na zawał, eksploatacja filarów przy użyciu strugów węglowych z załadunkiem urobku na przenośniki, zabezpieczenie rejonu wydobycia z wykorzystaniem obudowy zmechanizowanej oraz podpór hydraulicznych. Wydobycie w rejonie przodka odbywa się metodą ciaggła, przy użyciu wrębiarek.

Wykorzystywanie wrębiarek do wydobycia ścianowego nie jest nowością w kopalni Paskov, jednakże wykorzystywanie ich w kopalniach powoduje pewne problemy. Oprócz zagrożenia zapaleniem mieszanki metanu i powietrza, powstaje również mieszanina pyłu węglowego, metanu i powietrza, która okazuje się bardziej niebezpieczna nawet przy niskich stężeniach metanu i pyłu niż ich obecność w postaci pojedynczych składników w stężeniu odpowiadającym niskiej skłonności do wybuchu. Podjęto więc decyzję o stopniowym zastępowaniu wrębiarek przy eksploatacji przodków strugami węglowymi.

* VSB - TECHNICAL UNIVERSITY OF OSTRAVA, FACULTY OF MINING AND GEOLOGY, INSTITUTE OF MINING ENGINEERING AND SAFETY 


\begin{abstract}
W pracy dokonano obliczenia objętości metanu wydzielanego w wyniku prowadzenia wydobycia, określono stężenia metanu w trakcie prowadzenia prac, przeanalizowano możliwość zmniejszenia zagrożenia powstawania warstw metanu oraz efektywność promowanego systemy wentylacji przodka.
\end{abstract}

Słowa kluczowe: stężenie, metan, wentylacja, region przodka, wrębiarka, zagrożenie

\title{
1. Characteristics of the coal face n. 063608 at the Paskov mine
}

The Paskov Mine belongs to the company OKD, a.s.. The production of hard coking coal of the business groups $\mathrm{Va}$ and $\mathrm{Vb}$ started in 1970. The mining area is 42.51 square $\mathrm{km}$. The Paskov Mine is divided into the following parts: Staříč I in Sviadnov, Staříč II in Staříč and Staříč III in Chlebovice. The Paskov Mine is classified as a mine with coal and gas outburst hazard. (Hudecek et al. 2010)

The coal face will be lead along the joined seams 063 (17b) and 059 (16). According to the analogy with the coal faces n. 063 604, 063605,063606 and 063607 , and on the basis of the local prognosis tests carried out while preparatory mining workings, it is classified as the $1^{\text {st }}$ grade danger with respect to coal and gas outburst. (CGO). With respect to pressure bursts (PB), Staříč Plant of the Paskov Mine is not classified as a mine with pressure burst hazard.

Litostratigraphically, the seam $063(17 \mathrm{~b})$ as well as the seam 059 (16) belong to the upper part of Petřkovice layers of Ostrava formation. The average seam depth is $180 \mathrm{~cm}$ and it ranges from $120 \mathrm{~cm}$ to $210 \mathrm{~cm}$. It qualitatively corresponds to the business group Va, Vdaf content being above $15 \%$, ash up to $15 \%$. The underlying rocks consist of siltstone and arenaceous siltstone. The overlying rock is formed by ca. $4 \mathrm{~m}$ of mudstone, $12 \mathrm{~m}$ of siltstone above it with sharply settled mudstone layer ca. 8 m thick.

\subsection{Deposit conditions, tectonics}

The coal face is planned as one of the coal faces in continuous extraction of the seam 063 (17b), which is joined to the seam 059 (16) in the central part of the coal face. Due to the occurrence of tectonic dislocations of bedding thrust as well as subsidence character, the pressure of the overlying rocks and splitting seams, a considerable variability of seam dips as well as of seam thickness can be expected. Seam dips are oriented towards the northwest and range from $18^{\circ}$ to $32^{\circ}$. Tectonic disruption of the seam can be expected on the level of seam breaks in the amplitude of ca. $2 \mathrm{~m}$

Due to higher pressure load, more distinct tectonic disruption of the initial road and the workings (W) instability, it was necessary to extract around the coal face block approximately in the middle of the target length of the coal face n. 063 608. The workings formed a part of the extracted coal face n. 063607 deposited higher along the dip (a mining corridor for dual use). According to the assumption, for mining the coal face n. 063 608, the technology using the shearer KGE710F could be used; such attempts were already made at the Paskov Mine in the past, but the results were not very satisfactory, therefore this might be considered as a kind of experiment aiming at finding out whether sufficient irrigation and modified ventilation will solve significantly increased methane emissions while mining with shearer. 


\subsection{Excavation of the coal pillar using a shearer}

A narrow-swath shearer KGE-710F equipped with non-thrust feed system placed on the caving side of the coal face conveyor PF 4/832 was designed. The shearer is intended for using on both sides without the necessity to prepare recesses at the coal face bottom dead centres, while mining the seams with longitudinal dip of up to $35^{\circ}$ with the system of hydraulic brakes. Thanks to the built-in frequency converter, the speed the shearer shift is regulated continuously and automatically depending on the load on the excavation organs. Outer sprinkling through the sprinkling panels results in efficient decrease in dustiness and in the possibility of ignition of methane layers.

TABLE 1

Parameters of the shearer

\begin{tabular}{|l|c|c|}
\hline \hline \multicolumn{1}{|c|}{ Parameter } & $\begin{array}{c}\text { KGE-710F } \\
\text { (type of arm 710) }\end{array}$ & $\begin{array}{c}\text { KGE-710F } \\
\text { (type of arm 345) }\end{array}$ \\
\hline Maximum height of excavation $(\mathrm{mm})$ & 3,400 & 3,440 \\
\hline The excavation cylinder diameter $(\mathrm{mm})$ & 1,800 & 1,600 \\
\hline Swath width $(\mathrm{mm})$ & 800 & 800 \\
\hline Allowable longitudinal dip $\left(^{\circ}\right)$ & 35 & 35 \\
\hline Max. working feed speed $(\mathrm{m} / \mathrm{min})$ & 8 & 8 \\
\hline The distance between excavation members $(\mathrm{mm})$ & 10,864 & 10,832 \\
\hline
\end{tabular}

The Paskov Mine is a mine with coal and gas (mostly methane) outburst hazard, therefore it is necessary to follow the Decision of the District Mining Agency ref. n. 3895/2002, which means that narrow-swath mining is suitable there.

From the point of view of mining and machinery, shearer mining seems to be more advantageous than using a coal plough. It would mean that at the Staříč Mine, a shearer would be operated again after twenty seven years.

\section{The ventilation system}

\subsection{The ventilation of the whole mine}

For mine ventilation, a sucking system is used. Staříč Plant of the Paskov Mine is classified as a mine with coal and gas outburst hazard. Extraction of coal seams is accompanied by high coal gas capacity (in the period from 2002 to 2012, the relative coal gas capacity ranged from 33.4 cubic metres of $\mathrm{CH}_{4}$ to 72.0 cubic metres of $\mathrm{CH}_{4}$ ). The stated values depend on the composition of the extracted coal face blocks in individual mining fields, the efficiency of over-mining or undermining of the extracted coal face blocks starting in new areas of newly developed parts of mining fields, etc. (Zapletal et al., 2011).

The Paskov Mine consists of three separate ventilation areas with centrally located intake and return shafts and with ventilation blocks placed diagonally between the areas. The total length of the operated workings is about $124 \mathrm{~km}$. 


\subsection{The ventilation of the coal face n. 063608}

For the proposal of the ventilation of the coal face n. 063608 itself, there are two options, depending on the expected daily production with respect to methane emissions from duff coal into the atmosphere. The main indicator for selecting a suitable option is the compliance with the Regulation n. 22/1989 Coll. Section 83 Clause 4, stating that the concentrations of methane in mine air at places with workers must not exceed the limit of $1 \%$. According to the information available at the Paskov Mine, the expected volume ventilation flow at the coal face start is $10.9 \mathrm{~m}^{3} \cdot \mathrm{s}^{-1}$ at both upward and winze ventilation through the coal face, which amounts to $654 \mathrm{~m}^{3} \cdot \mathrm{min}^{-1}$ at the average cross section of the coal face with mechanical support, which is $3.8 \mathrm{~m}^{2}$.

However, it is clear that this is the case of average daily values. Immediate increase in methane concentration cannot be solved by increasing the ventilation volume flow in order to decrease the methane concentration to the required value of $1 \%$, therefore further measures must be taken. In the first place, efforts must be made to achieve higher efficiency of methane drainage in the coal face area, also the speed of the mining technology progress must be optimized, and the plant mine exception has to be determined. (Taraba et al., 2009)

\section{The main problems in ventilation and calculations of ventilation parameters}

\subsection{Coal gas capacity of the coal face}

The coal gas capacity of the coal face n. 063608 is determined using the results of the coal gas capacity (Taraba \& Pavelek, 2014) found out in situ during operation at the coal face n. 063607 . The value of the coal gas capacity coefficient $k_{p}$ of seams and rocks was determined as well $\left(k_{p}=2.91[-]\right)$. In further calculations of the ventilation, the value of the coal gas capacity of the particular coal seam of $4.17 \mathrm{~m}^{3} \mathrm{CH}_{4} \cdot \mathrm{t}^{-1}$ was used.

\subsection{The calculation of the volume of methane emitted as a result of excavation}

To calculate the volume of methane emitted from an excavated coal seam, the expected value of the relative coal gas capacity of the coal seam $P N_{u}=4,17 \mathrm{~m}^{3} \mathrm{CH}_{4} \cdot \mathrm{t}^{-1}$ was used.

The amount of emitted methane was calculated as the instantaneous value for the shearer travel per minute during excavation with travel speed of $5 \mathrm{~m} \cdot \mathrm{min}^{-1}$ in full width of the seam, with shearer cut working width of $0.8 \mathrm{~m}$ (the blade width). The shearer KGE $710 \mathrm{~F}$, whose maximum travel speed during coal excavation is $8 \mathrm{~m} \cdot \mathrm{min}^{-1}$, is considered for the coal face. Its speed during reverse, i.e. loading travel is $11 \mathrm{~m} \cdot \mathrm{min}^{-1}$. The average shearer travel speed during excavation was determined to be $5 \mathrm{~m} \cdot \mathrm{min}^{-1}$ and the corresponding methane emission per minute was used in the calculation (Beňová et al., 2012).

$$
E x=T \cdot P N_{u} \quad\left[\mathrm{~m}^{3} \mathrm{CH}_{4} \cdot \mathrm{min}^{-1}\right]
$$

where $E x$ is the amount of emitted methane $\left[\mathrm{m}^{3} \mathrm{CH}_{4} \cdot \mathrm{min}^{-1}\right]$ 


$$
T=z \cdot v \cdot m \cdot \rho
$$

where:

$z$ - working width, the blade width $0.8 \mathrm{~m}$;

$v$ - the speed of the shearer progress during excavation $5 \mathrm{~m} \cdot \mathrm{min}^{-1}$;

$m$ - the excavated seam width $1.83 \mathrm{~m}$;

$\rho$ - density of coal $1.32 \mathrm{t} \cdot \mathrm{m}^{-3}$, after substitution $T=9,66 \mathrm{t} \cdot \mathrm{min}^{-1}$.

$P N_{u}$ the coal gas capacity of the coal seam is $4.17 \mathrm{~m}^{3} \mathrm{CH}_{4} \cdot \mathrm{t}^{-1}$.

After substitution of the corresponding values in the calculation formula, the result is that the amount of methane emitted in mine air within one minute of shearer excavation will be $40.28 \mathrm{~m}^{3} \mathrm{CH}_{4} \cdot \mathrm{min}^{-1}$. This would be true on condition that all the gas is emitted during one minute, i.e. in fact, immediately.

It is clear that the amount of immediately emitting methane in mine air will decrease linearly with decreasing speed of shearer loader travel according to the linear dependence shown in Figure 1.

At the same time, in general, it holds true that, considering the planned daily coal production of $1,700 \mathrm{t}$, the amount of methane emitted in mine air as a result of excavation of coal substance (that is only from the excavated seam) is

$$
E x_{\text {day }}=T_{\text {day }} \cdot P N_{u}=1700 \cdot 4,17=7089 \quad \mathrm{~m}^{3} \mathrm{CH}_{4} \cdot \mathrm{day}^{-1}
$$

However, this is only true on condition that all the calculated emissions $E x_{d a y}$ will be emitted in the area of the coal face, regardless of the speed of transporting the mine run by the rake conveyer to the mining road.

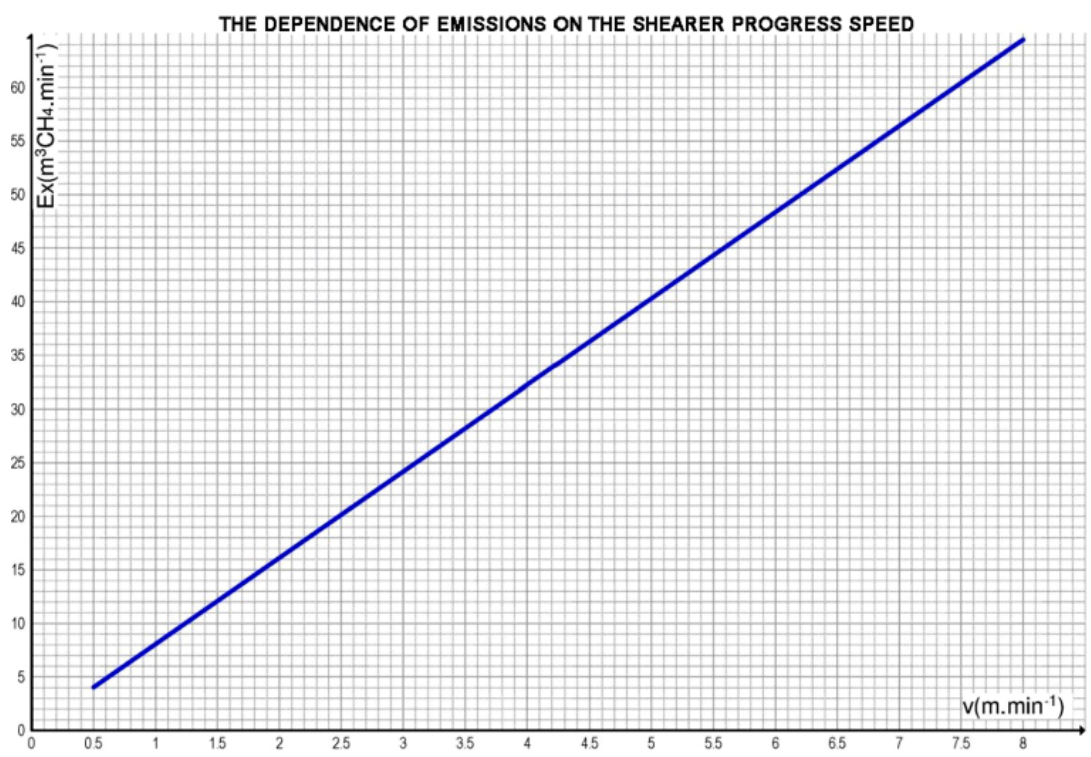

Fig. 1. The dependence of emissions on the shearer progress speed 


\subsection{Determining the methane concentration during excavation}

To determine the methane concentration during the coal seam excavation at the coal face, it is necessary to know the ventilation volume flow through the coal face, which will decrease the methane concentrations to the allowed values. This required the calculation of the ventilation volume flow through the intended workplace within the context of the ventilation network of the whole mine.

The value of the ventilation volume flow through the coal face was calculated as $Q_{v}=654 \mathrm{~m}^{3} \cdot \mathrm{min}^{-1}$, which is $10.9 \mathrm{~m}^{3} \cdot \mathrm{s}^{-1}$.

The calculation of the methane concentration at the place of the cutting blade was acquired by the substitution of the ventilation volume flow determined from modelling the ventilation network and methane emission during the coal seam extraction at the shearer progress speed of $5 \mathrm{~m} \cdot \mathrm{s}^{-1}$.

$$
c=c_{1}+\frac{100 \cdot E x}{Q_{v}}[\%]
$$

where

$c-$ is the methane concentration at the place of extraction [\%]

$c_{1}$ - is the methane concentration in mining ventilation at the workplace [\%]

$Q_{v}$ - is the ventilation volume flow $\left[\mathrm{m}^{3} \cdot \mathrm{min}^{-1}\right]$,

$E x$ - is the amount of emitted methane $\left[\mathrm{m}^{3} \mathrm{CH}_{4} \cdot \mathrm{min}^{-1}\right]$,

after the substitution of the values in the calculation formula, the result is

$$
c=0+\frac{100 \cdot 40.28}{654}=6.16 \%
$$

However, we cannot assume that the methane concentration in the ventilation, decreasing the methane emissions will reach zero value (Magnusková et al., 2011). This air mass will probably contain a certain volume of methane, which will penetrate into it while passing through the workings from the front shaft to the workplace. Therefore, for calculations, I recommend to consider the methane concentration of at least $0.1 \%$ in the air brought to the workplace (Bołoz, 2013).

The correctness of this calculation, however, is again based on the unrealistic assumption that all methane contained in the excavated coal mass and included in the coal gas capacity of the excavated coal seam itself is emitted within one minute, that is, in fact, immediately, and, moreover, in the whole volume. In fact, methane will be emitted gradually, and its concentration will be decreased immediately after it is released. Methane emissions in general correspond to the desorption curve, where emission starts after one minute, and during the following two minutes, 10 to $25 \%$ of gas, it is released from the coal mass.

The calculation is further based on the assumption that the shearer will travel at $5 \mathrm{~m} \cdot \mathrm{min}^{-1}$ during the excavation, at maximum use of the blade width. In this case we must also assume that such shearer operation will not be continual. However, there is one more condition here: that all the ventilation volume flow will be lead through the place of coal mass excavation, that is along the pillar (Dziurzyński et al., 2009).

It holds true that the methane concentration is directly proportional to the shearer loader progress and indirectly proportional to the ventilation volume flow through the workplace according to the dependence shown in Figure 2. 


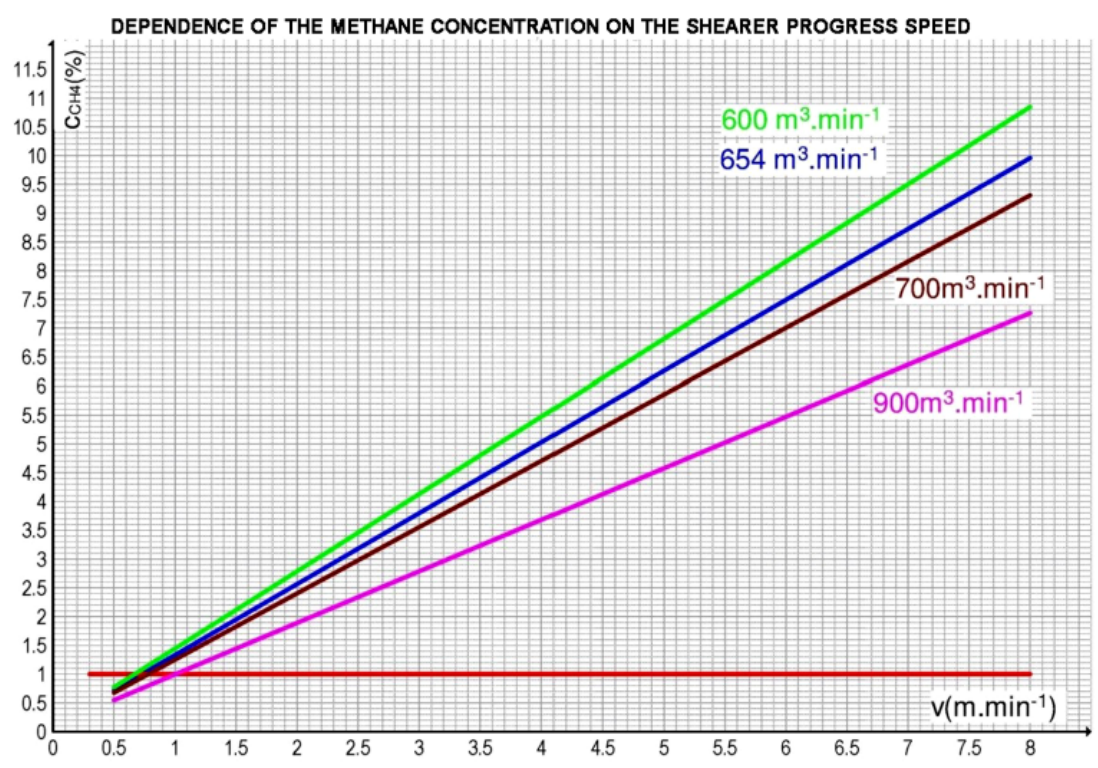

Fig. 2. Dependence of the methane concentration on the shearer progress speed

It is clear from the graph that increasing the ventilation volume flow to decrease methane concentrations to the required concentration, i.e. $1 \%$, does not represent a solution to the problem in this case. However, there are two other types of solutions. Firstly: to achieve the appropriate efficiency of methane drainage in the coal face area, and secondly: to optimize the speed of the shearer progress so that the allowed methane concentration should not be exceeded, and to take measures to prevent methane layers being formed at the coal face. Again, it is worth recalling that methane will not be emitted in the atmosphere immediately, but gradually (Berger et al., 2010).

Considering the fact that methane emissions from the coal mass which will be excavated at the coal face will not occur immediately and in the whole volume at once, it is more suitable to allow for the average methane concentrations during a longer time period while determining the methane concentration.

On the basis of the determined relative coal gas capacity from $300 \mathrm{~m}^{2}$ of the excavated area $P d_{r(300)}=12,14 \mathrm{~m}^{3} \mathrm{CH}_{4} \cdot \mathrm{t}^{-1}$, it can be concluded that it is the case of the coal face with a higher coal gas capacity.

\subsection{Determining the average daily methane concentration at the coal face}

At the expected $30 \%$ efficiency of methane drainage, the relative emission amounts to $E x_{r}=8.5 \mathrm{~m}^{3} \mathrm{CH}_{4} \cdot \mathrm{t}^{-1}$. This relative emission must be divided into emission from the affected accompanying rocks, i.e. overlying and underlying rocks of the excavated seam $\left(E x_{p}=4.33\right.$ $\mathrm{m}^{3} \mathrm{CH}_{4} \cdot \mathrm{t}^{-1}$ ), and emission originating from the coal face of the excavated coal substance $\left(E x_{u}=P N_{u}=4.17 \mathrm{~m}^{3} \mathrm{CH}_{4} \cdot \mathrm{t}^{-1}\right)$. Emission $E x_{u}$ must be further divided into the part originating from the coal substance mined by rake conveyer and coal pillar (20\%). According to desorption 
curve and the time of excavation from the coal face, $25 \%$ degassing of coal substance can be expected at the lowest point, i.e. at the coal face dead centre. However, with coal substance left at the coal face during the shearer excavation process, $45 \%$ degassing can be expected.

From emissions classified in this way, the maximum methane concentration at the coal face within 24 hours can be calculated, where Ex is substituted by the sum of values of methane emitted from the transported coal mass $\left(0.834 \mathrm{~m}^{3} \mathrm{CH}_{4} \cdot \mathrm{t}^{-1}\right)$, methane emitted from the coal left at the coal face $\left(0.3753 \mathrm{~m}^{3} \mathrm{CH}_{4} \cdot \mathrm{t}^{-1}\right)$ and the methane emitted from the affected accompanying rocks, i.e. the overlying and underlying rocks of the excavated seam $\left(4.33 \mathrm{~m}^{3} \mathrm{CH}_{4} \cdot \mathrm{t}^{-1}\right)$.

$$
c=\frac{100 \cdot E x \cdot T}{24 \cdot 60 \cdot Q_{v}}=\frac{100 \cdot 5.539 \cdot 1700}{24 \cdot 60 \cdot 654}=0.999=1 \%
$$

The maximum methane concentration within 24 hours suggests that with daily coal production of 1,700 t, it will certainly be the case of the coal face with higher coal gas capacity, however, that with optimum timing of the excavation, the planned ventilation volume flow through the coal face per day is sufficient enough to ensure that emitted methane is taken away and the concentration allowed by the Regulation n. 22/1989 Coll. is not exceeded.

This maximum methane concentration is connected to the critical, the most exposed place of the coal face, i.e. the bottom dead centre. Not to exceed it, according to my preliminary calculation, the value of the excavation travel at a certain length of the coal face is $1.22 \mathrm{~m} \cdot \mathrm{min}^{-1}$. Desorption of the loaded coal run takes place on the rake conveyer according to the description in chapter 3.3.

Within one minute after extraction and loading, the desorption has zero value, which means that at the beginning of the mining road, during this "non-gassing" minute, the coal run loaded on the rake conveyor will travel 57 metres along the coal face towards the mining road, or the extraction. For the remaining time of its movement, i.e. $1.63 \mathrm{~min}$, it will cover the remaining part of the route along the coal face with the expected desorption of $25 \%$ (within the period of $2.63 \mathrm{~min}$ ), which means that from the stationing $57 \mathrm{~m}$ (calculated from the bottom dead centre) there will be no desorption at the coal face on the rake conveyer towards the bottom dead centre, therefore the excavation travel speed at this part of the coal face will only be limited by the capacity of the rake conveyer (Dziurzynski at al., 2014).

At this point, it should be noted that with regard to the coal face configuration, where the upcast road is lower than the initial road, we cannot rely on the possibility of being granted an approval to increase the methane concentration to $1.5 \%$ according to Section 83 of the Regulation n. 22/1988 Coll., because the winze ventilation at the coal face excludes this possibility.

\subsection{Lowering the hazard of methane layers being formed}

The provision for eliminating the hazard of methane layers being formed consists in ensuring sufficient ventilation speed, which results in such turbulence of emitted methane that will prevent its layering at the ceiling of the workings where it may accumulate. The criterion for ensuring the necessary ventilation speed that will decrease the risk of forming the layers, is the layering number defined by Leach. To prevent methane layers being formed, the ventilation speed must be higher than the ventilation speed determined by the definition of Leach's layering number " $\mathrm{s}$ " 


$$
s=\sqrt[3]{\frac{24 \cdot v^{2}}{c \sqrt{S}}}[-]
$$

where:

$s$ - is the layering number,

$v-$ is the ventilation speed $\left[\mathrm{m} \cdot \mathrm{s}^{-1}\right]$,

$S-$ is the workings cross section $\left[\mathrm{m}^{2}\right]$,

$c-$ is the methane concentration in the workings profile [\%].

If the value of the layering number is higher than or equal to 2 , there is no danger of methane layers being formed in the particular conditions. The above mentioned calculation formula can be used to determine the limit methane concentration $c_{m}$ at which methane layers will not be formed yet:

$$
c_{m}=\frac{3 v^{2}}{\sqrt{S}}[\%]
$$

If the concentration is higher than the limit one, layers might be formed.

If we substitute in the calculation formula for determining the layering number the ventilation speed corresponding to the ventilation volume flow through the coal face decreased by $10 \%$ of loss due to caving (the loss was estimated as $Q_{p}=0.9 \cdot 10.9=9.8 \mathrm{~m} \cdot \mathrm{s}^{-1}$ therefore $v=\frac{9.8}{3.8}=2.6$ $\mathrm{m} \cdot \mathrm{s}^{-1}$ at the coal face) and the allowed methane concentration of $1 \%$, we find out that $s=4.4$, which is a value higher than 2 , so the condition for decreasing the hazard of methane layers being formed is met.

\section{Evaluating the suitability of the proposed system of ventilation of the coal face n. 063608}

With respect to the calculations connected with gradual desorption of the excavated coal run, the proposed system of ventilation " $Y$ " with the winze ventilation of the coal face must be mainly evaluated as, paradoxically, very advantageous and efficient. The valuable fact is that the ventilation flows through the coal face in the same direction as the mine run, so it does not allow the part of gas which is not desorbed until it reaches the mining road to return to the coal face. From an operational perspective, it is important that the shearer excavates in fresh ventilation and the space behind the progressing shearer is the least exposed part of the coal face both with respect to dustiness and methane emissions, which is, besides other things, highly significant for the shearer operator's safety (Dziurzynski et al., 2009).

The winze ventilation of the coal face may seem as a handicap, however, the simultaneity of the ventilation flow and the coal run movement on the rake conveyer has a highly positive impact on the possibility of the only way of control while maintaining the allowed methane concentration at the coal face. The proposed system is also advantageous in view of possible efficient methane drainage (presumably 30\%).

The only generally known significant disadvantage of this winze ventilation system is the necessity to keep the allowed methane concentration up to $1 \%$ with no possibility of being granted 
an exception. The calculations connected with evaluating the proposed ventilation system showed that the proposed provisions can ensure that the allowed concentration will not be exceeded even without being granted an exception.

A comparison with a possible alternative - introducing the ventilation system " $Y$ " with the upward ventilation of the coal face - showed that in the gas conditions where the rake conveyer moves at the coal face in the opposite direction than the ventilation flow, it is not possible to ventilate the coal face sufficiently enough to prevent exceeding the limit determined by the regulations, not even if an exception of $1.5 \%$ was granted (Prokop at al., 2010).

To illustrate, we state the calculation of the daily methane concentration with the upward ventilation of the coal face, considering only $10 \%$ efficiency of methane drainage and $100 \%$ degassing of all coal run, because emissions taken away by the ventilation from the mining road into the coal face must be included in the calculation of the emissions as well. According to the calculation formula mentioned above, the calculation will be as follows:

$$
c=\frac{100 \cdot E x \cdot T}{24 \cdot 60 \cdot Q_{v}}=\frac{100 \cdot 10.926 \cdot 1700}{24 \cdot 60 \cdot 654}=1.97 \%
$$

To calculate the immediate highest concentration (in this case it is the same value along the whole length of the coal face) the following calculation formula is used

$$
c=c_{1}+\frac{100 \cdot E x}{Q_{v}}=0+\frac{100 \cdot 16.586}{654}=2.53 \%
$$

It follows that with the upward ventilation of the coal face, it is possible to rely on being granted an exception of up to $1.5 \%$ of methane at the coal face, however, in this case, there is no point in this exception.

Other disadvantages of this ventilation system include the impossibility to maintain the mining road behind the coal face for the following coal face, a danger of flooding depending on the dip, penetration of methane to the upcast flow behind the coal face over the pack wall, and finally, making methane drainage from old workings impossible, including the above-mentioned increase in the methane concentration from the mining road due to the transported coal.

\section{Conclusions}

Using the shearer at mines in the south part of the OKR (the Ostrava-Karviná Coalfield), i.e. Paskov and Staříč, is not a novelty. On 15 July 1977, methane-air mixture was ignited by a friction spark at the Paskov Mine (the former Paskov Mine in Paskov), when the shearer cut into the accompanying rock with its blade (Lát, 1988). A decision was made then that shearers will gradually be replaced with coal ploughs in all coal faces. The same measures were also taken at the former Staříc Mine (the present-day Paskov Mine). The last shearer was put out of operation in 1986.

Shearer mining represents another problem. Besides the above mentioned hazard of methaneair ignition, there is a mixture of coal dust - methane - air, which is more dangerous even in the case of lower concentrations of dust and methane than their individual lower limits of explosiveness. 
A very significant hazard is represented by the fact that, compared to the coal plough, the shearer blade with the size of its working width means much more dynamic impact on the coal substance stability, mainly in connection with the phenomenon of the coal and gas outburst.

Gradual desorption of coal mass, as described above, does not mean that at the moment of extraction, part of methane found in the seam in a "free" state, not bound to coal substance, will not get within the vicinity of the blade. Immediate methane emission during extraction results from "free" methane released from rifts and micro cavities in the coal seam, or at the places of geological changes.

It is true that the present-day technology and the technical level of mining machines and mining equipment in general have undergone significant progress, however, this fact itself does not mean that shearer mining will be less hazardous.

The paper was written with the support of the SP 2013/ 73 Project - New Methods of Suppressing of Dustiness by Spraying in Coal Mines.

\section{References}

Beňová E., Koudelková J., Prokop P., Danihelka P., 2012. The analysis of the risks of the firedamp leakage at the Ostrava-Karvina mine district. Acta Montanistica Slovaca, Vol. 17, Iss. 2, p. 85-92.

Berger J., Markiewicz J., Dolega T., 2010. Influence of distance of exploitational front from drainage boreholes on thein efficiency with use the U ventilation systém. Arch. Min. Sci., Vol. 55, No 3, p. 561-571.

Bołoz Ł., 2013. Unique project of single-cutting head longwall shearer used for thin coal seams exploitation. Arch. Min. Sci., Vol. 58, No 4, p. 1057-1070.

Dziurzyński W., Krach A., Pałka T., 2009. Method of Regulating Elements of the Methane Drainage Network Using Computer Simulation. Arch. Min. Sci., Vol. 54, No 2, p. 159-187.

Dziurzyński W., Krach A., Pałka T., 2014. Computer simulation of the propagation of heat in abandoned workings insulated with slurries and mineral substances. Arch. Min. Sci., Vol. 59, |No 1, p. 3-23.

Hudeček V., Urban P., Stavinoha J., 2010. Problems of higher gas emission and coal and gas outbursts in countries of the word and in the Czech Republic. Journal of Mines, Metals and Fuels, 8/2010.

Lát J., 1988. Dobývání nizkých ploše uložených uhelných sloji ve složitých důlně geologických podmínkách. Dočasná vysokoškolská učebnice. Ministerstvo školství, mládeže a tělovýchovy, Praha.

Magnusková J., Matušková S., Bartoňová J., Pavelek Z., 2011. Problems of cooling sealed fire fields in underground coal mines. Journal of Mines, Metals \& Fuels. Vol. 59, No. 10, October 2011, p. 321-327.

Prokop P., Zapletal P., Fiurášková D. 2010. Re-Opening of the Longwall No. 28731 Sealed Due to Spontaneous Combustion of Coal. Arch. Min. Sci., Vol. 55, No 3, p. 537-547.

Taraba B., Pavelek Z., SlovákV., Janek J., 2009. Effect of Pre-Treatment of the Coal on its Oxidation Behaviour. Mine Ventilation, Volume 2). Ninth International Mine Ventilation Congress, India, Oxford \&IBH Publishing Co. Pvt. Ltd. New Delhi.

Taraba B., Pavelek Z., 2014. Investigation of the spontaneous combustion susceptibility of coal using the pulse flow calorimetric method: 25 years of experience. Fuel, 1 25, DOI: 10.1016/j.fuel.2014.02.024.

Zapletal P., Prokop P., Dorazil V., 2011. The Regulation of Ventilation by Changing The Operation of The Main Fan and its Impact on The Face Worked under The Main Haulage Level. GeoScience Engineering, VS̆B-TU Ostrava. 